\title{
Neoarchean and Paleoproterozoic re-activation of the crust-mantle transition beneath the central Kaapvaal craton, Lace kimberlite
}

\author{
Desmond E. Moser \\ Jack Satterly Geochronology Laboratory, Royal Ontario Museum, 100 Queenís Park, Toronto. \\ M5S 2C6, Canada
}

Rodger J. Hart

Schonland Research Centre, University of the Witwatersrand, Johannesburg, P.O. Box Wits 2050, South Africa

The structural and metamorphic evolution of the crust-mantle transition of the Kaapvaal craton is poorly understood. Yet the record of activity along this fundamental chemical and rheological boundary within the lithosphere is of general importance to understanding the evolution of the underlying diamondiferous mantle. As a complement to our ongoing studies of exposed deep crust and upper mantle in the Vredefort crustal cross-section, we are completing a U-Pb zircon dating study of lower crustal xenoliths and an eclogite xenolith from the Lace kimberlite, $150 \mathrm{~km}$ southwest of the Vredefort structure. The Lace kimberlite is known for its relative abundance of crustal xenoliths of both felsic and mafic compositions. A previous study of felsic sapphirine-bearing xenoliths (paragneiss) reported equilibration in the granulite-facies, and a complicated pattern of zircon dates interpreted to reflect metamorphism at ca. $2.58 \mathrm{Ga}$ (Dawson et al., 1997). Our study has focused on $\mathrm{U}-\mathrm{Pb}$ zircon dating of a subordinate population of granulite- facies mafic xenoliths.

We have selected five xenoliths for study, and these range in composition from garnet pyroxenite to garnet-clinopyroxene metagabbro. The metamorphic assemblages suggests equilibration at pressures of between $0.8 \mathrm{GPa}$ and $1.2 \mathrm{GPa}$. The pyroxenite is very coarse-grained whereas the grain size within single metagabbro xenoliths ranges from very fine grained to coarse with fine-grained bands. The fine-grained bands correspond to mylonitic seams in which all minerals exhibit evidence of grain-size reduction. Quartz ribbons are locally preserved. Zircon from the coarse grained xenoliths is generally euhedral and prismatic suggesting primary crystallization from a liquid, whereas highly sheared samples yield grains that are dominantly anhedral and highly-resorbed. Cathodoluminescence imaging reveals concentric planar growth banding within the euhedral grains, and this is consistent with an igneous origin. Resorbed zircons exhibit planar growth banding that is truncated by the grain surface, and, locally, is overprinted by brightly luminescent unzoned patches that extend from the edge of the grain. High precision isotope dilution analysis of single euhedral and resorbed grains, and fragments of imaged grains, has been carried out in order to date the time of primary and secondary crystallization.

Our present data set points to episodes of late Archean and mid-Proterozoic activity in the Kaapvaal lower crust. Zircons from three of the five xenoliths define a discordia line intersecting 
concordia at $2682+/-7 \mathrm{Ma}$ (2 sigma), with euhedral grains giving least discordant results. This late Archean age is interpreted to date the primary crystallization of the gabbros in the lower crust, and represents the first evidence for Neoarchean (Ventersdorp?) magmatic intraplating of the Kaapvaal lithosphere. Interestingly, the intrusion of basaltic magmas into the lower crust beneath Lace coincides broadly with re-setting of some Ar/Ar geochronometers in the Barberton Greenstone Belt to the northeast (Lopez-Martinez et al., 1992) and with melting of deep crust at Vredefort (Moser and Hart, unpublished data). Although the horizontal and vertical extent of $2.68 \mathrm{Ga}$ intraplating remains unresolved, the coincidence of this event with some Re-Os model ages for mantle nodules (Pearson et al., 1995) suggests that it may have played a significant role in the thermal evolution of domains within the Kaapvaal lithosphere.

The lower intercept of the zircon discordia line is less precise, giving an intercept age of $2038+/$ $27 \mathrm{Ma}$ ( 2 sigma). Resorbed zircon grains yield the most discordant analyses. This age determination overlaps the ages of both the $2.06 \mathrm{Ga}$ Bushveld event (Walraven et al., 1990) and 2020+/-3 Ma Vredefort impact event (Moser, 1997). The greater abundance of the resorbed zircons in the finegrained, mylonitized metagabbros permits the interpretation that the resorption and recrystallization of zircon accompanied the shearing event. Based on our parallel study of Vredefort lower crust, which fails to reveal any deep-crustal Bushveld-aged metamorphic assemblages, it is likely that recrystallization and, perhaps, deformation in the deep crust beneath Lace was precipitated by the Vredefort impact event. As with the $2.68 \mathrm{Ga}$ event, the pervasiveness of Vredefort-related reactivation of the Kaapvaal lithosphere remains to be ascertained. We have recently discovered zircons in an eclogitic xenolith from Lace, and the results from this mantle sample will be presented for comparison with the chronology of lower crustal events described above.

\section{References}

Dawson, J.B., Harley,S.L., Rudnick,R.L., and Ireland, T.R., 1997, Equilibration and reaction in Archaean quartz-sapphirine granulite xenoliths from the Lace kimberlite pipe, South Africa: Journal of Metamorphic Geology, 15, p. 253-266.

Lopez-Martinez, M., York, D. Hanes, J.A., 1992, A 40Ar/ 39Ar geochronological study of komatiites and komatiitic basalts from the lower Onverwacht Volcanics; Barberton Mountain Land, South Africa: Precambrian Research. 57, p. 91-119.

Moser, D.E., 1997, Dating the shock wave and thermal imprint of the giant Vredefort impact, South Africa: Geology, 25, p. 7-10.

Pearson, D.G., Carlson,R.W., Shirey,S.B., Boyd, F.R., Nixon, P.H., 1995, Stabilisation of Archaean lithospheric mantle; a Re-Os isotope study of peridotite xenoliths from the Kaapvaal Craton: Earth and Planetary Science Letters, 134, p. 341-357. 
Walraven, F., Armstrong, R. A., Kruger, F. J., 1990, A chronostratigraphic framework for the northcentral Kaapvaal Craton, the Bushveld Complex and the Vredefort Structure: Tectonophysics, 171, p. 23-48. 